\title{
Imports and Economic Growth: Algeria as a Case Study 1990-2010
}

\author{
Guennouni Habib
}

\author{
Tsabet Abderrahmane \\ Adouka Lakhdar \\ Professor Mascara University (Algeria)
}

\section{Doi:10.5901/mjss.2014.v5n10p127}

\begin{abstract}
This study aims to measure the impact of imports on the economic growth in Algeria, basing on time series from 1990 up to 2010, as the study shows that Algeria has proceeded to liberalize its trade since 1990. It indicates the Algerian imports' tendency to EU countries and the countries of North America. The study indicates also the importance of imports in the Algerian economy since the latter is yield. The study has confirmed the contribution of each of the raw materials and industrial supplies positively on economic growth, which confirms Algeria's adoption on imports in the productive sector to the outside world (where the contribution of each unit of the raw materials and industrial supplies was 22.21 and 5.97 in Gross Domestic Product GDP), and through this study, we have used the Error Correction Model. Finally, the study indicates that imports, through their impact on growth, modify during nearly half a year.
\end{abstract}

Keywords: Imports, Economic Growth, Error Correction Model.

\section{Introduction}

Foreign trade is considered as the main artery that connects countries to each other. It is the important part in the national economy of any country. It is also considered as the main channel for the disposal of surplus production on the one hand, and the country can get the resources it needs from other countries on the other hand. The term "foreign trade" is of great interest to economics due to its effective contribution on the process of economic development, especially in developing countries.

Since the $18^{\text {th }}$ century, economists have tried to give explanations to the reasons for establishing the international trade, starting from the classical theory to the modern theory, through which several opposing economic ideas appeared between those who advocate a policy of protection and others who call for liberalization of foreign trade, and each thought has its own justifications.

Importing goods and services in foreign trade is an important part of the local economy, as it gets through it the goods and services that can not be produced or viewed on a better relative advantage of other countries. Imports work for creating the appropriate conditions for growth through providing production requirements and raw materials and equipment and machinery needed for the various sectors of economic activity. Furthermore, imports of consumer goods are important to cover the growing needs of the community, as a result of the increase in incomes and population. It enhances the standard of living for individuals through their consumer spending on imported goods and services. Thus, imports are significant and strategic. Besides, it raises the level of domestic investment and thus increases the productive capacity of the economic sectors through importing capital commodities.

It is undoubtedly that the only goal behind the international exchange adopted by states is to achieve economic growth which is one of the most important economic indicators and the goal of any economic policy sine on the one side, it reflects the reality of economic performance in general, then it highlights the economic situation, this can clarify the economic visions and highlight the direction in which the economy goes. On the other side, it reflects the improvement of the welfare of community members.

Therefore, economic growth is a phenomenon that has different dimensions: It is an economic phenomenon that shows the existence of an overlap and integration in economic activity combinations. It is also considered as a social phenomenon for its social effects on the structure of the community. Perhaps the economic and social dimensions of the growth increase its complexity, and perhaps the most dominant in analyzing the phenomenon of economic growth is the adoption of economic and social approaches to understand and interpret it. That is why we find some economic studies 
try to understand only the nature of economic growth without attempting to understand the complex relationships and causes that affect it and its variability.

Regarding the different views of economists in the nature of the relationship between foreign trade (imports or exports) and economic growth.

What impact and contribution have the imports on the Algerian economic growth?

\section{Literature Review}

\subsection{Foreign trade a an engine of economic growth:}

The study of Al Sharif Bader (1995) entitled "Strategy of the Substitution of Imports and Economic Growth in Jordan": It aims to test the hypotheses of the effect of the substitution of imports on economic growth in Jordan during the period 1970-1993, where it included that the substitution of imports on economic growth is inverse, which means that the increase of imports affects positively the economic growth and this shows the Jordanian economy's dependence on imports. It has been shown that the growth of the gross domestic product depends on imports; either it is capitalist, raw or consumer materials. The study showed that consumer imports were less significant in static but they were positive.

The study of Samer Abdul Mahdi Al Rajoub: "Imported Capital Goods and its role in the Growth of the Jordanian Economy. A Standard analytical study (1970-1995): To test the contribution of the imported capital goods in achieving economic growth, Al Rajoub used time series of Jordan during (1970-1995). The study concluded that the effect of imported goods is positive and has a high significant statistics so that an increase in the value of imports of capital goods by one million dinars would increase the gross domestic product. When examining the relationship between imports of capital goods and their exports, we found a weak relationship between the imports and the exports. As the coefficient of imports of capital goods explains that the increase of the quantities of those goods by one dinar will work to increase exports of capital goods by (0.022) of dinar, which is very low rate. The study also found that the rate of imports of capital goods to the local product has a positive effect on the growth in Jordan and it is demonstrated by the value of the rate of coefficient which reached $(0.6)$ and which showed that by fixing the values of workers' compensation and the rate of investment to the gross domestic product, the country can grow faster if it uses the imported capital goods at a higher rate than local product, to build the accumulation of its stock from the capital.

Finally, the study recommends the need to interest on improving the state of the local productive base, so that in the future, it becomes able to produce all its needs of capital goods which can produce their counterparts and support the local productive situation, therefore exports. In order to improve the conditions of the local productive base, there must be an import of cheap capital goods from the developed industrial countries, which own a huge stock of capital accumulation to the ultimate production of the capitalist formation. The study also recommends the need of interest on the planning process of the imported content which is appropriate to the goals of economic and industrial development through the preparation of detailed plans specialized in the import activity, and they shall be linked to the plan of local production which suits the needs of capital goods such as machinery and equipment which are considered as one of the basic necessities for the conduct of the production process.

The study of Al Tai and Al Kawaze (1999) entitled "The Impact of Aggregate and Detailed Imports on Economic Growth in the Hashemite Kingdom of Jordan during 1975-1995": The problematic of the study was the contribution of imports on the gross domestic production in Jordan during the period mentioned. It concluded the positive and moral impact of the imports on the gross domestic product in Jordan by using the following form:

$Y=B_{0}+B_{1} M+B_{2} T+\varepsilon$

Where:

Y: gross domestic product

M: total imports

T: time

The study considered that the result is logical since Jordan is one of the developing countries, and there are some reasons that decide this effect: the beginning of the period of research represents the economic development in which investment requirements are expanded as well as the increase of spending on development projects, which leads to the increase in the demand for various imports to promote commodity sectors, especially the industrial sectors in Jordan.

The study ha been strengthened by estimating the impact of imports in detail by replacing the variable of total import by detailed imports (capital goods MK, consumer goods MC, raw materials MR and other imports MO), as well as time. So that the form became:

$Y=B_{0}+B_{1} M K+B_{2} M C+B_{3} M R+B_{4} M O+\varepsilon$ 
The results concluded that the impact of capital imports is positive and has a moral indication, and this is expected as the imports of capital goods occupy a leading role in economic growth, especially in the early stages, through its impact on investment.

The study of Lawrence and Weinstein (1999): it dealt with the importance of imports in achieving high growth rates. The study was done on two states, Japan and Korea on the importance of liberalization and tariff reduction. It indicated that if the Japanese government pursued this policy during (1964-1973), it would achieve better results than those achieved by following the policy of protection, due to the importance of foreign competition to stimulate creativity, learning and the possibility of assessing inputs and better materials. This study also demonstrated that the imports of noncompetitive goods for local products have a weak impact on growth, unlike competitive goods. The study also confirmed the importance of imports for the Korean economy.

The study of Thangavelu and Rajaguru (2004): it aimed to test the causal relationship between imports and exports and productivity in nine fast-growing Asian countries, using the Error Correction's model, where the results indicated the important impact of foreign trade on economic growth, and when testing the causal relationship, no relationship has been proven in the long term of exports to economic growth as measured by productivity growth in Hong Kong, Indonesia, Japan, Taiwan and Thailand, while the results showed the causal relationship of imports to economic growth in India, Indonesia, Malaysia, the Philippines, Singapore and Taiwan. The study concluded that the impact of imports greater than that of the exports on economic growth in the long term. Imports are considered, in this study, as the main link between foreign trade and economic growth.

\subsection{Foreign trade is disincentive for economic growth}

The study of Erletis (1992): it examined the causal relationship using Test Causality Ranger between imports and exports and the growth of the Gross National Product (GNP) of Canada during 1970-1985. Erletis did the test "unit roots and cointegration" of the variables of the study. He concluded that the GNP and exports and imports are not related (cointegrated). His main conclusion was that economic growth strategy is by the expansion of exports to increase national income, as the study considers that imports achieve negative impacts; therefore, they do not contribute to economic growth, where Ordinary Least Square (OLS) method was used.

The study of Baliamoune-Lutz (2004): it aimed to measure the relationship between foreign trade investment and imports and exports to Morocco, using the test of causality "GRANGER", depending on the time series during 1973-1999. the results indicated that economic growth does not cause foreign direct investment (FDI) in Morocco, which a very reasonable result because many of Europeans, especially the French companies, began commercial operations in Morocco during the colonial era and continued to expand independently of economic growth in the short term (i.e., the study showed that there is no impact of imports on economic growth.)

The study of Jin (2004): Jin analyzed the economic openness and the economic growth (the scholar uses the word openness to mean exports and imports) of 17 provinces and 3 Chinese bodies and he wanted to realize whether the relationship between economic openness and economic growth is valid through seven coastal provinces and isolated provinces that were 17. Jin set his model on the basis of the usual production function, including technological change, which depends on the degree of the economic openness in the country. He got a positive and moral result for the coastal provinces and a negative result for the isolated provinces that represent most of the areas surveyed by the study. He concluded that isolated areas, which do not have seaward port, do not have enough good economy to foreign competition.

The study of Nadia Lemzoudi: It studied the impact of trade openness in the coastal and inland states on the economic growth. The study included a group of developing countries: Benin, Burkina Faso, Ghana, Mali, Niger, and Nigeria during 1980-2002, using the same methodology as Jin, relying on the functions of production and using time series for the period mentioned and the criterion which is the total of exports and imports. The following form was set by this study:

Where: K: capital element, L: work item, T: technological development (which was replaced by OPEN that shows the openness.) The study adopted the following model:

$L Y_{T}=B 0+B_{1} L K_{T}+B_{2} L O P E N+\varepsilon T$

The result obtained is that there is a positive relationship between trade openness and the economic growth rate for two of three coastal states, while there is a negative relationship for the three other internal countries, which are Burkina Faso, Mali and Niger. This study suggests that the internal states should be less 


\section{Empirical Study}

\subsection{Giving the model}

The model that we want to study has the following form:

$Y_{t}=\beta_{0}+\beta_{1} M_{1}+\beta_{2} M_{2}+\beta_{3} M_{3}+\beta_{4} M_{4}+\beta_{5} M_{5}+\beta_{6} M_{6}+\beta_{7} M_{7}+\varepsilon_{i}$ Where:

$Y_{t}:$ The rate of growth of GDP

$\mathrm{M}_{2}$ : imports of energy and oil

$\mathrm{M}_{1}$ : represents the imports of food

M4: imports of semi-finished materials

$\mathrm{M}_{3}$ : imports of raw materials

M6: imports of industrial supplies

Ms: imports of agricultural equipment

$\mathrm{M}_{7}$ : imports of industrial consumer goods

\subsection{The stationary of the time series}

Table (1) : stationary of Series $y_{t}$

\begin{tabular}{|c|c|c|c|c|c|c|}
\hline \multirow{2}{*}{ Type of Model } & \multicolumn{2}{|c|}{ Model 3 } & \multicolumn{2}{c|}{ Model 2 } & \multicolumn{2}{c|}{ Model 1 } \\
\cline { 2 - 7 } & $\begin{array}{c}\text { ADF value at } \\
5 \%\end{array}$ & ADF value calculated & $\begin{array}{c}\text { ADF value at } \\
5 \%\end{array}$ & $\begin{array}{c}\text { ADF value } \\
\text { calculated }\end{array}$ & $\begin{array}{c}\text { ADF value at } \\
5 \%\end{array}$ & $\begin{array}{c}\text { ADF value } \\
\text { calculated }\end{array}$ \\
\hline Original Series & -3.65 & -1.77 & $3.65-$ & 0.57 & $1.95-$ & 1.60 \\
\hline Divisive Series of first class dyt & -3.67 & -6.14 & $3.02-$ & $5.20-$ & -1.86 & $1.88-$ \\
\hline
\end{tabular}

Source: prepared by the researcher, depending on the program eviews 7

Since the statistical value of the calculated ADF is more than the scheduled at $5 \%$ (in absolute value) at the first difference in the third models, as well as the direction and the fix are not signify, so the series $\mathrm{yt}_{\mathrm{t}}$ is stable of the first-class. $\mathrm{Y}_{\mathrm{T} \rightarrow(1)}$

Table (2): stationary of Series $M_{1}$

\begin{tabular}{|c|c|c|c|c|c|c|}
\hline \multirow{2}{*}{ Type of Model } & \multicolumn{2}{|c|}{ Model 3} & \multicolumn{2}{|c|}{ Model 2} & \multicolumn{2}{|c|}{ Model 1} \\
\hline & ADF value at 5\% & ADF value calculated & ADF value at $5 \%$ & ADF value calculated & ADF value at $5 \%$ & ADF value calculated \\
\hline Original Series & -3.73 & -0.77 & \begin{tabular}{|l|}
-3.06 \\
\end{tabular} & \begin{tabular}{|c|}
0.40 \\
\end{tabular} & -1.96 & 0.73 \\
\hline $\mathrm{dM} 1$ & -3.75 & 1.37 & -3.08 & -0.13 & 1.96 & 1.30 \\
\hline ddM1 & -3.73 & -8.01 & 1.96- & -3.08 & 1.53- & 1.96- \\
\hline
\end{tabular}

Source: prepared by the researcher, depending on the program eviews 7

Since the statistical value of the calculated ADF is more than the scheduled at $5 \%$ (in absolute value) at the second difference in the third models, as well as the direction and the fix are not signify, so the series $M_{1}$ is stable of the secondclass. $\mathbf{M}_{1 \rightarrow 1(2)}$

Table (3): stationary of Series $M_{2}$

\begin{tabular}{|c|c|c|c|c|c|c|}
\hline \multirow{2}{*}{ Type of model } & \multicolumn{2}{|c|}{ Model 3} & \multicolumn{2}{|c|}{ Model 2} & \multicolumn{2}{|c|}{ Model 1} \\
\hline & ADF value at $5 \%$ & ADF value calculated & ADF value at $5 \%$ & ADF value calculated & ADF value at $5 \%$ & ADF value calculated \\
\hline Original Series & $3.67-$ & 2.701 & $3.02-$ & .4 .51 & 1.96 & 3.85 \\
\hline $\mathrm{dM} 2$ & 3.71- & $0.75-$ & $3.05-$ & 0.27 & 1.96 & 0.80 \\
\hline ddM2 & $3.75-$ & $1.45-$ & $3.04-$ & $11.90-$ & -1.96 & $11.98-$ \\
\hline
\end{tabular}

Source: prepared by the researcher, depending on the program eviews 7

Since the statistical value of the calculated ADF is more than the scheduled at $5 \%$ (in absolute value) at the second difference in the third models, as well as the direction and the fix are not signify, so the series $\mathrm{M}_{2}$ is stable of the secondclass. $\mathbf{M}_{\mathbf{2} \rightarrow \mathbf{1}(2)}$ 
Table (4): stationary of Series $M_{3}$

\begin{tabular}{|c|c|c|c|c|c|c|}
\hline \multirow{2}{*}{ Type of model } & \multicolumn{2}{|c|}{ Model 3 } & \multicolumn{2}{c|}{ Model 2 } & \multicolumn{2}{c|}{ Model 1 } \\
\cline { 2 - 7 } & ADF value at 5\% & ADF value calculated & ADF value at 5\% & ADF value calculated & ADF value at 5\% & ADF value calculated \\
\hline Original Series & -3.65 & $1.75-$ & $3.02-$ & $0.24-$ & 1.95 & 0.78 \\
\hline dM3 & $3.69-$ & $4.97-$ & $3.02-$ & $5.20-$ & $1.96-$ & $4.86-$ \\
\hline
\end{tabular}

Source: prepared by the researcher, depending on the program eviews 7

Since the statistical value of the calculated ADF is more than the scheduled at $5 \%$ (in absolute value) at the first difference in the third models, as well as the direction and the fix are not signify, so the series $M_{3}$ is stable of the firstclass. $\mathbf{M}_{3 \rightarrow 1(1)}$

Table (5): stationary of Series $\mathrm{M}_{4}$

\begin{tabular}{|c|c|c|c|c|c|c|}
\hline \multirow{2}{*}{ Type of model } & \multicolumn{2}{|c|}{ Model 3 } & \multicolumn{2}{c|}{ Model 2 } & \multicolumn{2}{c|}{ Model 1 } \\
\cline { 2 - 7 } & ADF value at 5\% & ADF value calculated & ADF value at 5\% & ADF value calculated & ADF value at 5\% & ADF value calculated \\
\hline Original Series & $3.67-$ & $1.99-$ & $3.02-$ & $.2 .09-$ & 1.96 & 0.44 \\
\hline $\mathrm{dM} 4$ & $4.61-$ & 2.05 & $3.65-$ & $3.05-$ & $4.23-$ & $1.96-$ \\
\hline $\mathrm{ddM} 4$ & $3.69-$ & $7.60-$ & $3.04-$ & $6.52-$ & -1.96 & 2.03 \\
\hline
\end{tabular}

Source: prepared by the researcher, depending on the program eviews 7

Since the statistical value of the calculated ADF is more than the scheduled at $5 \%$ (in absolute value) at the second difference in the third models, as well as the direction and the fix are not signify, so the series $\mathrm{M}_{4}$ is stable of the secondclass. $\mathbf{M}_{4 \rightarrow 1(2)}$

Table (6): stationary of Series $M_{5}$

\begin{tabular}{|c|c|c|c|c|c|c|}
\hline \multirow{2}{*}{ Type of Model } & \multicolumn{2}{|c|}{ Model 3 } & \multicolumn{2}{c|}{ Model 2 } & \multicolumn{2}{c|}{ Model 1 } \\
\cline { 2 - 7 } & ADF value at 5\% & ADF value calculated & ADF value at 5\% & ADF value calculated & ADF value at 5\% & ADF value calculated \\
\hline Original Series & $3.65-$ & $1.20-$ & $3.02-$ & 0.26 & 1.95 & 1.18 \\
\hline dM5 & $3.67-$ & $5.45-$ & $3.02-$ & $4.18-$ & $1.96-$ & $4.10-$ \\
\hline
\end{tabular}

Source: prepared by the researcher, depending on the program eviews 7

Since the statistical value of the calculated ADF is more than the scheduled at $5 \%$ (in absolute value) at the first difference in the third models, as well as the direction and the fix are not signify, so the series $\mathrm{M}_{5}$ is stable of the firstclass. $\mathbf{M}_{5 \rightarrow I(1)}$

Table (7): stationary of Series $M_{6}$

\begin{tabular}{|c|c|c|c|c|c|c|}
\hline \multirow{2}{*}{ Type of Model } & \multicolumn{2}{|c|}{ Model 3 } & \multicolumn{2}{c|}{ Model 2 } & \multicolumn{2}{c|}{ Model 1 } \\
\cline { 2 - 7 } & ADF value at 5\% & ADF value calculated & ADF value at 5\% & ADF value calculated & ADF value at 5\% & ADF value calculated \\
\hline Original Series & $3.69-$ & 0.93 & $3.04-$ & .2 .28 & $1.96-$ & 2.71 \\
\hline $\mathrm{dM6}$ & $3.69-$ & $5.07-$ & $3.05-$ & $0.80-$ & $1.96-$ & 0.23 \\
\hline $\mathrm{ddM6}$ & $3.71-$ & $6.14-$ & $3.05-$ & $6.43-$ & -1.96 & 6.04 \\
\hline
\end{tabular}

Source: prepared by the researcher, depending on the program eviews 7

Since the statistical value of the calculated ADF is more than the scheduled at $5 \%$ (in absolute value) at the second difference in the third models, as well as the direction and the fix are not signify, so the series $M_{6}$ is stable of the secondclass. $\mathbf{M}_{6 \rightarrow 1(2)}$

Table (8): stationary of Series $\mathrm{M}_{7}$

\begin{tabular}{|c|c|c|c|c|c|c|}
\hline \multirow{2}{*}{ Type of Model } & \multicolumn{2}{|c|}{ Model 3 } & \multicolumn{2}{c|}{ Model 2 } & \multicolumn{2}{c|}{ Model 1 } \\
\cline { 2 - 7 } & ADF value at 5\% & ADF value calculated & ADF value at 5\% & ADF value calculated & ADF value at 5\% & ADF value calculated \\
\hline Original Series & $3.69-$ & 1.30 & $3.04-$ & 3.07 & $1.96-$ & 3.12 \\
\hline dM7 & $3.69-$ & $5.22-$ & $3.02-$ & $4.12-$ & $1.96-$ & 1.71 \\
\hline
\end{tabular}

Source: prepared by the researcher, depending on the program eviews 7

Since the statistical value of the calculated ADF is more than the scheduled at $5 \%$ (in absolute value) at the first difference in the third models, as well as the direction and the fix are not signify, so the series $M_{7}$ is stable of the firstclass. $\mathbf{M}_{\mathbf{7} \rightarrow \mathbf{I}(1)}$ 


\subsection{Co integration Test}

Since we have more than one variable (multiple regression), so the most effective test to find relationships of simultaneous integration between dependent variables and explanatory variables is the test of JOHANSAN. It is done between $\left(y_{t}, m_{3}, m_{5}, m_{7}\right)$ because $Y t$ is stable of the first-class and it is the same stability for $\left(m_{7}, m_{5}, m_{3}\right)$ while variables $\left(m_{1}\right.$, $\mathrm{m}_{2}, \mathrm{~m}_{4}, \mathrm{~m}_{6}$ ) are stable of the second-class, and there is no room of cointegration with Yt for the difference in the degree of stability.

Table (9): Test of trace

\begin{tabular}{|c|c|c|c|c|}
\hline \multicolumn{5}{|c|}{ Date: 06/13/12 Time: 12:35 } \\
\hline \multicolumn{5}{|c|}{ Sample (adjusted): 19922010} \\
\hline \multicolumn{5}{|c|}{ Included observations: 19 after adjustments } \\
\hline \multicolumn{5}{|c|}{ Trend assumption: Linear deterministic trend } \\
\hline \multicolumn{5}{|c|}{ Series: YT M3 M5 M7 } \\
\hline \multicolumn{5}{|c|}{ Lags interval (in first differences): 1 to 1} \\
\hline \multicolumn{5}{|c|}{ Unrestricted Cointegration Rank Test (Trace) } \\
\hline Hypothesized & & Trace & 0.05 & \\
\hline No. of CE(s) & Eigenvalue & Statistic & Critical Value & Prob.* \\
\hline None * & 0.899610 & 93.75577 & 47.85613 & 0.0000 \\
\hline At most 1 * & 0.812495 & 50.08056 & 29.79707 & 0.0001 \\
\hline At most 2 * & 0.485131 & 18.27554 & 15.49471 & 0.0186 \\
\hline At most 3 * & 0.257718 & 5.662506 & 3.841466 & 0.0173 \\
\hline \multicolumn{5}{|c|}{ Trace test indicates 4 cointegrating eqn(s) at the 0.05 level } \\
\hline \multicolumn{5}{|c|}{ * denotes rejection of the hypothesis at the 0.05 level } \\
\hline **MacKinnon- & 999) p-values & & & \\
\hline
\end{tabular}

Source : taken from Eviews7

We conclude that there are 4 relationships of simultaneous integration (as JOHANSAN Test based on testing the effect to determine the number of relationships) as shown in the table above. Thus, the correct assessment model is the use of Error Correction model (ECM).

\subsection{Error Correction Model}

\subsubsection{Estimating the general model in the long term}

Table (10): Estimating the general model in the long term:

\begin{tabular}{|c|c|c|c|c|}
\hline \multicolumn{5}{|c|}{ Dependent Variable: YT } \\
\hline \multicolumn{5}{|c|}{ Method: Least Squares } \\
\hline \multicolumn{5}{|c|}{ Date: 06/13/12 Time: $12: 47$} \\
\hline \multicolumn{5}{|c|}{ Sample: 19902010} \\
\hline \multicolumn{5}{|c|}{ Included observations: 21} \\
\hline Variable & Coefficient & Std. Error & t-Statistic & Prob. \\
\hline C & -9685.710 & 11695.57 & -0.828152 & 0.4225 \\
\hline M1 & 16.52109 & 7.524864 & 2.195533 & 0.0469 \\
\hline M2 & 11.59773 & 42.95653 & 0.269988 & 0.7914 \\
\hline M3 & 24.37659 & 20.90631 & 1.165992 & 0.2646 \\
\hline M4 & -0.228226 & 0.255570 & -0.893007 & 0.3881 \\
\hline M5 & 23.18237 & 62.86416 & 0.368769 & 0.7182 \\
\hline M6 & 10.41311 & 3.148939 & 3.306863 & 0.0057 \\
\hline M7 & -21.09635 & 10.48342 & -2.012353 & 0.0654 \\
\hline R-squared & 0.967685 & \multicolumn{2}{|c|}{ Mean dependent var } & 77695.57 \\
\hline Adjusted R-squared & 0.950284 & \multicolumn{2}{|c|}{ S.D. dependent var } & 42138.43 \\
\hline S.E. of regression & 9395.638 & \multicolumn{2}{|c|}{ Akaike info criterion } & 21.41621 \\
\hline Sum squared resid & $1.15 \mathrm{E}+09$ & \multicolumn{2}{|c|}{ Schwarz criterion } & 21.81412 \\
\hline Log likelihood & -216.8702 & \multicolumn{2}{|c|}{ Hannan-Quinn criter. } & 21.50257 \\
\hline F-statistic & 55.61219 & \multicolumn{2}{|c|}{ Durbin-Watson stat } & 1.878710 \\
\hline Prob(F-statistic) & 0.000000 & & & \\
\hline
\end{tabular}

Source: taken from Eviews7 


\subsubsection{Estimating the Error Correction Model}

Table (11): Estimating the Error Correction Model:

\begin{tabular}{|c|c|c|c|c|}
\hline \multicolumn{5}{|c|}{ Dependent Variable: $\mathrm{D}(\mathrm{YT})$} \\
\hline \multicolumn{5}{|c|}{ Method: Least Squares } \\
\hline \multicolumn{5}{|c|}{ Date: 06/13/12 Time: $12: 54$} \\
\hline \multicolumn{5}{|c|}{ Sample (adjusted): 19912010} \\
\hline \multicolumn{5}{|c|}{ Included observations: 20 after adjustments } \\
\hline Variable & Coefficient & Std. Error & t-Statistic & Prob. \\
\hline ECT(-1) & -0.574360 & 0.316542 & -1.964486 & 0.0527 \\
\hline $\mathrm{D}(\mathrm{M} 1)$ & 14.35900 & 4.403214 & 3.261028 & 0.0068 \\
\hline $\mathrm{D}(\mathrm{M} 2)$ & 48.12036 & 42.02248 & 1.145110 & 0.2745 \\
\hline $\mathrm{D}(\mathrm{M} 3)$ & 22.21279 & 14.31710 & 1.751487 & 0.1067 \\
\hline $\mathrm{D}(\mathrm{M} 4)$ & -0.135133 & 0.213681 & -0.632407 & 0.5390 \\
\hline $\mathrm{D}(\mathrm{M} 5)$ & -70.27591 & 58.19075 & -1.207682 & 0.2504 \\
\hline $\mathrm{D}(\mathrm{M} 6)$ & 5.977012 & 2.756293 & 2.168497 & 0.0509 \\
\hline $\mathrm{D}(\mathrm{M} 7)$ & -12.69327 & 7.240124 & -1.753184 & 0.1051 \\
\hline R-squared & 0.843404 & \multicolumn{2}{|c|}{ Mean dependent var } & 5006.755 \\
\hline Adjusted R-squared & 0.752056 & \multicolumn{2}{|c|}{ S.D. dependent var } & 14833.83 \\
\hline S.E. of regression & 7386.350 & \multicolumn{2}{|c|}{ Akaike info criterion } & 20.94183 \\
\hline Sum squared resid & $6.55 \mathrm{E}+08$ & \multicolumn{2}{|c|}{ Schwarz criterion } & 21.34012 \\
\hline Log likelihood & -201.4183 & \multicolumn{2}{|c|}{ Hannan-Quinn criter. } & 21.01958 \\
\hline Durbin-Watson stat & 1.898030 & & & \\
\hline
\end{tabular}

Source : taken from Eviews7

Where: ECT (-1)represents the rest of the model in the long term, after being delayed one year.

The model is formed as the following:

$D(y t)=-0,57^{*} E_{t-1}+14,36^{*} d(m 1)+22,21 * d(m 3)+5,97^{*} d(m 6)-12,69 * d(m 7)$

\subsection{A statistical and an econometrical analyses of the model}

Student's test (t) indicates that the variables $D(M 1), D(M 6)$ are statistically moral at $5 \%$ and the variables $D(M 3), D(M 7)$ are signify at $10 \%$, while the rest of the variables are not signify statistically (since the probability corresponding of Student's statistic is over 10\%.)

The coefficient of error correction (ECT) is negative and signify statistically. This emphasizes the necessity to use Error Correction Model for the right estimation.

The coefficient of determining is 0.7520 , it indicates the increase of explanatory power of the variables under the study (i.e. $75.20 \%$ of in GDP are due to the independent variables and $24.80 \%$ are due to the random variables.

The statistic DW $=1.89$ indicates that the model is free of errors of the first class.

\subsection{Testing the normal distribution of residuals}

Figure 1: natural distribution of residuals:

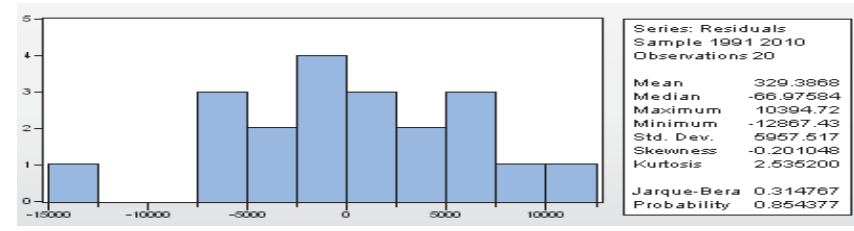

Source: taken from Eviews 7.

Since the probability corresponding of the statistic Jarque-bera $(J B)$ is more than $0.05(\operatorname{pr}(J B)=0,85>0.05)$, so null hypothesis is accepted, which shows that residuals follow the normal distribution. 


\subsection{Testing the homogeneity}

Table (12): ARCH Test

Source: taken from Eviews 7.

\begin{tabular}{|c|l|c|c|}
\hline \multicolumn{5}{|c|}{ Heteroskedasticity Test: ARCH } \\
\hline F-statistic & 0.002297 & Prob. F(1,17) & 0.9623 \\
\hline ObsR-squared & 0.002567 & Prob. Chi-Square(1) & 0.9596 \\
\hline
\end{tabular}

Since the probability corresponding of $\mathrm{F}$ for ARCH Test is more that $0.05(\operatorname{pr}(\mathrm{f})=0,96>0.05)$, we accept the null hypothesis which shows that the contrast of residuals is homogeneous.

\subsubsection{Testing the structural stability of the model (CUSUM), (CUSUMQ):}

Figure (2): Testing the stability of Error Correction Model

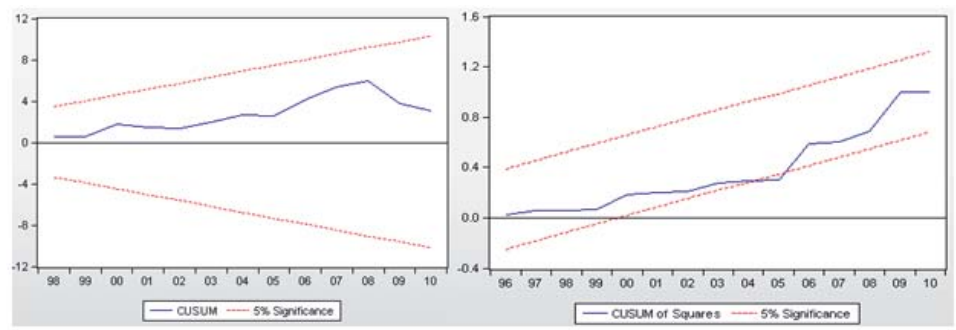

Source: taken from Eviews 7.

Since each of the statistics CUSUM and CUSUMQ are within the confidence limits at 5\%, so the model is structurally stable.

\subsubsection{Testing the model's ability of prediction:}

Figure (3): Errors' changing in the model:

Source: Taken from Eviews 7.

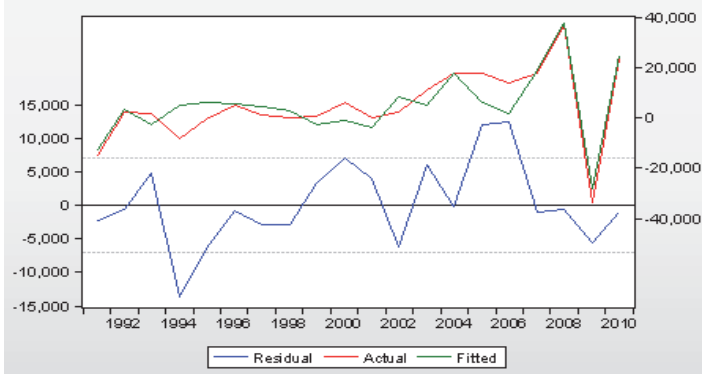

We note from the figure that the estimated variable Yt generally follow the same path of the real variable, in other words, the change of the errors in the model is convergent. This gives more credibility to the model.

Through the previous points, we deduce the ideal standard formula of the model, which is:

$\mathrm{D}(\mathrm{yt})=-0,57^{*} \mathrm{E}_{\mathrm{t}-1}+14,36^{\star} \mathrm{d}(\mathrm{m} 1)+22,21^{*} \mathrm{~d}(\mathrm{~m} 3)+5,97^{*} \mathrm{~d}(\mathrm{~m} 6)-12,69^{*} \mathrm{~d}(\mathrm{~m} 7)$

\subsection{The economic analysis of the results}

The coefficient (ect) is negative and equal to -0.57 . this value means that when one of the explanatory variables changes, the dependent variables (Yt) change too, and it altered down by $57 \%$, in other words, the values alter almost every half a year from the short to the long term. 
- Whenever the imports of food increase by one unit, the GDP increases by 14.36 units.

- Whenever the imports of raw materials increase by one unit, the GDP increases by 22.21 units.

- Whenever the imports of industrial supplies increase by one unit, the GDP increases by 5.97 units.

- Whenever the imports of consumer goods increase by one unit, the GDP decreases by 12.69 units.

\section{Conclusion}

Various experimental studies and growth models, which dealt with the relationship between imports (even directly, by talking about international trade or trade liberalization) and growth emphasized the importance of imports in achieving the economic growth. They focused also on the strong relationship between these two variables, as shown by the thoughts of Classics, Neoclassicals and keynes.

This does not preclude the existence of studies which proved the contrary that the imports have a negative impact on economic growth, especially in developing countries, as shown by Marxism and Structuralism.

As for the relationship between imports and economic growth in Algeria, we tried to use the Error Correction Method. The study has shown, according to this model, the positive impact of both imports of food, raw materials and industrial equipment on economic growth by the rates 14.36, 22.21 and 5.97 respectively. Besides, the imports alter almost every half a year to influence the GDP.

\section{References}

\section{Books}

Ahmed Djamel Eddine Moussa, "economic relationship and development theory", new eljalae library, Elmansoura, Egypt, 1999. (Arb). John Adlman Sirrou, Khaled Kacem tradition, " politics international economics' relationships", Jordanian center books, Jordan, 1987. (Arb).

Michel Toudarou, "economic development", elmarikh house, riadh, 2006. (Arb).

Mohamed Abd Alaziz Ajimia \& Mohamed Ali Alithi, "economic development (concept, theories and politics)", new university house, Alexandria, 2003. (Arb).

Zineb Hocine Aoudh Allah, " international economic", new university house, alexandry, 2004. (Arb).

\section{Theses}

Abdellah Moussaoui, "the role of international trade in development strategy during (1989-1999)", Alger's University, Algeria, 2002. (Arb). Abd Errachid Ben Eddib, "organization and development of Algerian international trade", Alger's University, Algeria, 2003. (Arb).

Bibi Youcef, "economic policy for international trade liberalization under WTO, case of Algeria", Alger's University, Algeria, 2007. (Arb).

Nadia Lemzoudi, « effect of liberalization degrees on economic growth, case of six west African countries », research rapport, Montréal University, 2005. (Fr).

Rouaba Mohamed, «study of trade liberalization effect on economic growth in developing countries, used PANIL coefficient", Chlef University, Algeria, 2011. (Arb).

Yahiaoui Mohamed Salah, « effect of trade liberalization on economic growth, case of Algeria (1976-2009) », national high school of statistic and economic apply, Algeria, 2011. (Fr).

Ziada Mohamed Arafat Abou Leila, "effect of foreign direct investment and importation on Jordan's economic growth", Yarmouk University, Jordan, 2004. (Arb).

\section{Articles}

Khaled Elkhathlan, "the problem of relationship between export and economic growth in developing countries (morocco case, used OLS), article in the King Saoud university, Riyadh. (Arb). 